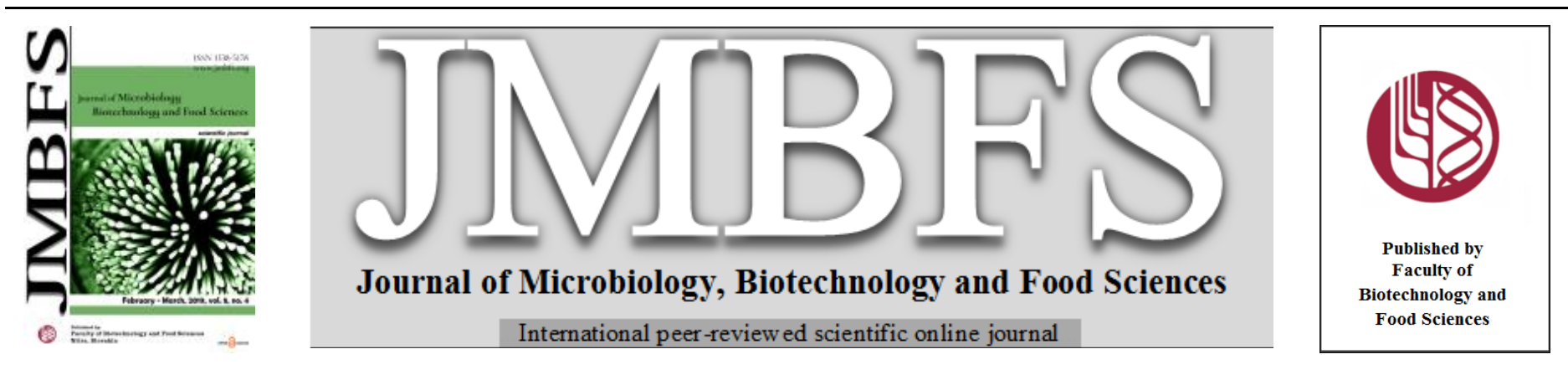

\title{
PHYTOCHEMICAL PROFILE AND ANTIOXIDANT ACTIVITY OF WATER PEPPER (POLYGONUM HYDROPIPER
} L.)

\author{
Dasha Mihaylova ${ }^{1}$, Radka Vrancheva ${ }^{2}$, Ivan Ivanov $^{3}$, Aneta Popova $^{4}$ \\ Address(es): Dasha Mihaylova, PhD \\ ${ }^{1}$ University of food technologies, Technological Faculty, Biotechnology, 26 Maritsa blvd., 4000 Plovdiv, Bulgaria. \\ ${ }^{2}$ University of food technologies, Technological Faculty, Analytical chemistry and physicochemistry, 26 Maritsa blvd., 4000 Plovdiv, Bulgaria. \\ ${ }^{3}$ University of food technologies, Technological Faculty, Organic Chemistry and Inorganic Chemistry, 26 Maritsa blvd., 4000 Plovdiv, Bulgaria. \\ ${ }^{4}$ University of food technologies, Economics Faculty, Catering and tourism, 26 Maritsa blvd., 4000 Plovdiv, Bulgaria.
}

*Corresponding author: dashamihaylova@yahoo.com

doi: 10.15414/jmbfs.2019.8.5.1205-1208

ARTICLE INFO

Received 8. 10. 2018

Revised 31. 12. 2018

Accepted 10. 1. 2019

Published 1. 4. 2019

Regular article

open ${ }_{\text {ACCESS }}$

\begin{abstract}
Polygonum hydropiper L. (water pepper), an important medicinal plant from the Polygonaceae family, is traditionally used in folk medicine as an anti-cancer and anti-rheumatic agent, against diarrhea, positively influencing cerebral ischemia, Parkinson's disease, and with neuroprotective effects. The aim of the current study was to evaluate and compare the total polyphenol content and antioxidant activity of water (infusion, decoction and microwave) and alcohol (tincture) extracts of Polygonum hydropiper. The total flavonoid content, total monomeric anthocyanin content and detailed phenolic acids profile were additionally assessed. The polyphenol content was established to be in range from $5.02 \pm 0.07$ to $17.44 \pm 0.24 \mathrm{mg} \mathrm{GAE} / \mathrm{g} \mathrm{dw}$, the total flavonoids from $3766.27 \pm 118.25$ to $6909.66 \pm$ $66.03 \mu \mathrm{M} \mathrm{QE} / \mathrm{g} \mathrm{dw}$ and total monomeric anthocyanins from $0.26 \pm 0.14$ to $3.17 \pm 0.44 \mathrm{mg} / \mathrm{l}$. The in vitro antioxidant activity was evaluated by four common procedures, the highest results were established for the decoction, and tincture extracts. The phenolic acids profile revealed the highest yield, in respect of total phenolic acids, in the water pepper tincture $-3243.74 \mu \mathrm{g} / \mathrm{g} \mathrm{dw}$. As a result, the consumption of $P$. hydropiper extracts could be recommended as a good source of biologically active substances with potential benefit
\end{abstract} effects.

Keywords: Polygonum hydropiper, antioxidant potential, water extracts, tincture, phenolic acids profile

\section{INTRODUCTION}

Polygonum hydropiper L. (Persicaria hydropiper, water pepper) is one of the most numerous geniuses in the family Polygonaceae, which has a long history of use in folk medicine as remedy for the treatment of a multiplicity of disorders (Ayaz et al., 2015). The plant is distributed from the tropics in the Northern hemisphere to the temperate zone and grows wildly in watersides and marshes (Loi, 2000). It has been used as a hot-tasting spice in Europe and other countries, and as a folk medicine for cancer and haemostatics (Haraguchi et al., 1992). In Vietnam, the stems and leaves of this plant are used to treat snake-bites and are known as diuretic and anthelmintic agents (Loi, 2000). In India, Polygonum sp., has been traditionally used to treat diuretic, CNS stimulant, diaphoretic, stomachic, styptic, in bleeding and in diarrhea (Sharma, 2003). Other species of the Polygonaceae family have been reported for their effectiveness in cerebral ischemia (Chan et al., 2003), Parkinson's disease (Chen et al., 2007) and neuroprotective effects (Li et al., 2005). The presence of flavonoids with antioxidant activity, aldose reductase and tyrosinase inhibitory activities has been reported in this plant (Haraguchi et al., 1996; Peng et al., 2003; Miyazawa and Tamura, 2007).

Medicinal plants have been widely used to treat a variety of infectious and noninfectious diseases. The Bulgarian flora includes 4,300 species, over 500 of which are rare or endemic to the country or the Balkan region (Ivancheva and Stancheva, 2001).

Phenolic compounds are one of the most widely occurring groups of phytochemicals in nature. They have considerable physiological and morphological importance in plants. In particular, several research studies carried out the biological activity of this group of phytochemicals. The antioxidant activity of polyphenols is due to their ability to scavenge free radicals, donate hydrogen atoms or electron, or chelate metal cations (Amarowicz et al., 2004; Balasundram et al., 2006).

Based on the differences in the structure of phenolic compounds, their solubility in solvents of different polarity varies. Therefore, the extraction solvent type as well as the isolation procedures themselves may have a significant impact on the extraction yield of plants material polyphenols.

The previously mentioned and the necessity of consumers to be aware of any possible biological potential of the plants employed in the everyday life defined the aim of the present manuscript. This paper deals with the antioxidant properties, total polyphenolic content and phytochemical profile in respect of phenolic acids in order to highlight the potential biological activities in extracts of this medicinal plant.

\section{MATERIAL AND METHODS}

\section{Extracts preparation}

The samples of Polygonum hydropiper L. (stems of water pepper) were obtained from a local pharmacy (Plovdiv, Bulgaria) in 2016. The plant parts were dried, ground and stored at ambient temperature in air-tight containers prior to extraction. Four extraction procedures were performed as follows: water (infusion, decoction and microwave extraction) and $70 \%$ ethanol (v/v, tincture) Two extraction solvents (water and $70 \%$ ethanol) were used by applying the extraction methods - infusion, decoction, microwave extraction, and tincture in particular.

The infusion was obtained by pouring $50 \mathrm{~mL}$ boiling water into $2.5 \mathrm{~g}$ of plant material and left for $30 \mathrm{~min}$ to cool down. Water decoction was retrieved by boiling $2.5 \mathrm{~g}$ of plant material in $50 \mathrm{~mL}$ water for $30 \mathrm{~min}$; Microwave-assisted extract (MAE) experiment was carried out in a domestic microwave oven (LG MB4047C) where $2.5 \mathrm{~g}$ of plant material was subjected to $2450 \mathrm{MHz}$ frequency waves for 30 seconds, at $800 \mathrm{~W}$ output power with $50 \mathrm{~mL}$ water .

The tincture was obtained with ethanol $(70 \%, \mathrm{v} / \mathrm{v})$ with periodic manual agitation for a period of seven days, left in the dark, at room temperature. The material/solvent ratio used was 1:10 (w/v). All extracts were filtered after preparation and stored at $4{ }^{\circ} \mathrm{C}$ without adding any preservatives until analyses. 


\section{Determination of total polyphenolic content (TPC)}

The TPC was analyzed following the method of Kujala et al. (2000) with some modifications. Each extract $(0.1 \mathrm{ml})$ was mixed with $0.5 \mathrm{ml}$ Folin-Ciocalteu reagent and $0.4 \mathrm{ml} 7.5 \% \mathrm{Na}_{2} \mathrm{CO}_{3}$. The mixture was vortexed and left for $5 \mathrm{~min}$ at $50{ }^{\circ} \mathrm{C}$. After incubation, the absorbance was measured at $765 \mathrm{~nm}$. The TPC was expressed as mg gallic acid equivalents (GAE) per g dry weight (dw)

\section{Total flavonoid content}

The total flavonoid content was evaluated according to the method described by Kivrac et al. (2009). An aliquot of $0.5 \mathrm{ml}$ of the sample was added to $0.1 \mathrm{ml}$ of 10 $\% \mathrm{Al}\left(\mathrm{NO}_{3}\right)_{3}, 0.1 \mathrm{ml}$ of $1 \mathrm{M} \mathrm{CH}_{3} \mathrm{COOK}$ and $3.8 \mathrm{ml}$ of ethanol. After incubation at room temperature for $40 \mathrm{~min}$, the absorbance was measured at $415 \mathrm{~nm}$. Quercetin was used as a standard and the results were expressed as $\mu \mathrm{M} \mathrm{QE} / \mathrm{g} \mathrm{dw}$.

\section{Total monomeric anthocyanin content}

The total monomeric anthocyanin content was determined using the $\mathrm{pH}$ differential method (AOAC Official Method 2005.02). Properly diluted samples were mixed with $\mathrm{KCl}(0.025 \mathrm{M}, \mathrm{pH} 1.0)$ and $\mathrm{CH}_{3} \mathrm{COONa}(0.4 \mathrm{M}, \mathrm{pH} 4.5)$ with an appropriate dilution factor. Absorbance (A) was measured using UV-Vis spectrophotometer at 520 and $700 \mathrm{~nm}$ after $15 \mathrm{~min}$ incubation at room temperature, and the results were calculated as follows:

$\mathrm{A}=\left(\mathrm{A}_{520}-\mathrm{A}_{700}\right) \mathrm{pH} 1.0-\left(\mathrm{A}_{520}-\mathrm{A}_{700}\right) \mathrm{pH} 4.5$

The monomeric anthocyanin (MA) pigment concentration in the samples was calculated as:

Monomeric anthocyanin pigment $(\mathrm{mg} /$ liter $)=(\mathrm{A} \times \mathrm{MW} \times \mathrm{DF} \times 1000) /(\varepsilon \times 1)$ where $\mathrm{M}$ represents the molar mass of cyanidin-3-glycoside $(449.2 \mathrm{~g} / \mathrm{M}), \mathrm{DF}$ is the dilution factor, $\varepsilon$ is molar extinction coefficient $(26,9001 / \mathrm{M} \mathrm{x} \mathrm{cm})$, and 1 is the cuvette optical path length $(10 \mathrm{~mm})$. The final anthocyanin concentration is expressed as milligram per $1000 \mathrm{ml}$ of sample of cyanidin-3-glycoside.

\section{Determination of antioxidant activity}

$D P P H^{*}$ radical scavenging assay: The ability of the extracts to donate an electron and scavenge 2,2-diphenil-1-picrylhydrazyl (DPPH) radical was determined by the slightly modified method of Brand-Williams et al. (1995) as described by Mihaylova et al. (2015). Freshly prepared $0.4 \mathrm{mM}$ solution of DPPH was mixed with the samples in a ratio of 2:0.5 (v/v). The light absorption was measured at $517 \mathrm{~nm}$ after $30 \mathrm{~min}$ incubation at room temperature. The DPPH radical scavenging activity was presented as a function of the concentration of Trolox - Trolox equivalent antioxidant capacity (TEAC) and was defined as the concentration Trolox having equivalent antioxidant activity expressed as the $\mu \mathrm{M}$ per $\mathrm{g} d w(\mu \mathrm{M} \mathrm{TE} / \mathrm{g} \mathrm{dw})$

\section{ABTS $^{\bullet+}$ radical scavenging assay}

The radical scavenging activity of the extracts against 2,2'-azino-bis(3ethylbenzothiazoline-6-sulfonic acid) $\left(\mathrm{ABTS}^{\cdot+}\right)$ was estimated according to Re et al. (1999). Briefly, ABTS radical cation $\left(\mathrm{ABTS}^{*+}\right)$ was produced by reacting ABTS stock solution $(7 \mathrm{mM})$ with $2.45 \mathrm{mM}$ potassium persulfate (final concentration) and allowing the mixture to stand in the dark at room temperature for $12-16 \mathrm{~h}$ before use. Afterward, the $\mathrm{ABTS}^{\cdot+}$ solution was diluted with ethanol to an absorbance of $0.7 \pm 0.02$ at $734 \mathrm{~nm}$ and equilibrated at $30{ }^{\circ} \mathrm{C}$. After the addition of $1.0 \mathrm{ml}$ of diluted $\mathrm{ABTS}^{++}$solution to $0.01 \mathrm{ml}$ of samples, the absorbance reading was taken at $30{ }^{\circ} \mathrm{C}$ after $6 \mathrm{~min}$. The results were expressed as TEAC value ( $\mu \mathrm{M}$ TE/g dw)

\section{Ferric-reducing antioxidant power (FRAP) assay}

The FRAP assay was carried out according to the procedure of Benzie and Strain (1999) with slight modification. The FRAP reagent was prepared fresh daily and was warmed to $37^{\circ} \mathrm{C}$ prior to use. One-hundred and fifty microliters of plant extracts were allowed to react with $2850 \mu \mathrm{l}$ of the FRAP reagent for $4 \mathrm{~min}$ at $37^{\circ} \mathrm{C}$. The absorbance was recorded at $593 \mathrm{~nm}$ and the results were expressed as $\mu \mathrm{M} \mathrm{TE} / \mathrm{g} \mathrm{dw}$.

\section{Cupric ion reducing antioxidant capacity (CUPRAC) assay}

The CUPRAC assay was carried out according to the procedure of Apak et al. (2004). One $\mathrm{ml}$ of $\mathrm{CuCl}_{2}$ solution $(10 \mathrm{mM})$ was mixed with $1 \mathrm{ml}$ of neocuproine methanolic solution $(0.0075 \mathrm{mM}), 1 \mathrm{ml} \mathrm{NH}_{4} \mathrm{Ac}$ buffer solution $(\mathrm{pH} 7.0)$, and 0.1 $\mathrm{ml}$ of herbal extract (sample) followed by addition of $1 \mathrm{ml}$ water (total volume = $4.1 \mathrm{ml}$ ) and mixed well. Absorbance against a reagent blank was measured at 450 $\mathrm{nm}$ after $30 \mathrm{~min}$. Trolox was used as a standard and the results were expressed as $\mu \mathrm{M}$ TE/g dw.

\section{Identification and quantification of phenolic acids}

Qualitative and quantitative determination of phenolic acids was performed by using Elite LaChrome (Hitachi) HPLC system equipped with DAD and ELITE LaCHrome (Hitachi) software. Separation of the phenolic acids was performed on Supelco Discovery HS C18 column $(5 \mu \mathrm{m}, 25 \mathrm{~cm} \times 4.6 \mathrm{~mm})$, operated at 30 ${ }^{\circ} \mathrm{C}$ under gradient conditions with mobile phase consist of $2 \%(\mathrm{v} / \mathrm{v})$ acetic acid (solvent A) and acetonitrile (solvent B) as reported by Terzieva et al. (2017). The gradient program used was: $0-1 \mathrm{~min}-95 \% \mathrm{~A}$ and $5 \% \mathrm{~B} ; 1-40 \mathrm{~min}: 50 \% \mathrm{~A}$ and $50 \% \mathrm{~B}$; 40-45 min: $100 \% \mathrm{~B}$; 46-50 min: $95 \% \mathrm{~A}$ and $5 \% \mathrm{~B}$. The detection of phenolic acids was carried out at $280 \mathrm{~nm}$ for gallic, protocatechuic and cinnamic acids and at $320 \mathrm{~nm}$ for chlorogenic, caffeic, ferulic, p-coumaric, sinapic, rosmarinic and chicoric acids. The flow rate was $0.8 \mathrm{ml} / \mathrm{min}$.

\section{RESULTS AND DISCUSSION}

Table 1 is a visual presentation of the results in respect of the total phenolic content, total flavonoid content and total monomeric anthocyanins occurring in the investigated extracts. The established total phenolic content varied between $5.02 \pm 0.07$ and $17.44 \pm 0.24 \mathrm{mg} \mathrm{GAE} / \mathrm{g} \mathrm{DW}$. The maximum polyphenolic extraction yield $(17.44 \pm 0.24 \mathrm{mg} \mathrm{GAE} / \mathrm{g} \mathrm{dw})$ was obtained in the tincture extract. The same tendency was observed regarding the total flavonoid content $(3766.27 \pm 118.25-6909.66 \pm 66.03 \mu \mathrm{M} \mathrm{QE} / \mathrm{g} \mathrm{DW})$ and total monomeric anthocyanins, where the presence of monomeric anthocyanins in the infusion and microwave extracts was not even detected. In comparison, Nurain et al. (2006) reported TFC of water pepper water and ethanol extracts $-424.17 \pm 36.67$ and $589.33 \pm 12.83 \mathrm{mg} \mathrm{QE} / \mathrm{g}$ extract and Zulfiker et al. (2011) detected TPC of $964.230 \mathrm{mg} \mathrm{GAE} / \mathrm{g} \mathrm{dw}$ for $97 \%$ methanol extract.

According to the results from the phytochemical profile of $P$. hydropiper the tincture possesses higher activity among all investigated extracts. This is possibly due to the use of ethanol as solvent. Polar solvents are frequently used for recovering polyphenolic compounds from plant matrices. The most suitable solvents are aqueous mixtures containing ethanol, methanol, acetone, and ethyl acetate. The higher the polarity, better the solubility of the compounds (Naczk and Shahidi, 2006). Ethanol is known as a good polyphenol extraction solvent and safe for human consumption. The addition of water to the ethanol improves the extraction rate. Among the water extracts decoction appeared as the most suitable technique. Water is a polar solvent, with a density, viscosity, and activity, which can impair solubility, transfer or contact with the matrix. Furthermore, water has benefits as a green extraction solvent because it is not only inexpensive and environmentally benign; but is also non-flammable, nontoxic, providing opportunities for clean processing and pollution prevention. Finally yet importantly, water is easy accessible by consumers. A higher temperature of extraction can increase solvent-matrix interaction too.

Table 1 Total phenolic content (mg GAE/g DW), total flavonoid content ( $\mu \mathrm{M} \mathrm{QE} / \mathrm{g} \mathrm{DW}$ ) and total monomeric anthocyanins content (mg/l) of P. hydropiper (water pepper) extracts

\begin{tabular}{lccc} 
Extraction technique & Total polyphenolic content & Total flavonoid content & $\begin{array}{c}\text { Total monomeric } \\
\text { anthocyanins }\end{array}$ \\
\hline Infusion & $5.02 \pm 0.07$ & $3766.27 \pm 118.25$ & - \\
Decoction & $7.58 \pm 0.21$ & $6385.35 \pm 728.05$ & $0.26 \pm 0.14$ \\
Microwave & $5.84 \pm 0.07$ & $2050.58 \pm 100.23$ & - \\
Tincture & $17.44 \pm 0.24$ & $6909.66 \pm 66.03$ & $3.17 \pm 0.44$ \\
\hline ““ - not
\end{tabular}

The antioxidant potential of the studied $P$. hydropiper extracts was evaluated by four different in vitro assays (DPPH and ABTS antiradical activities; FRAP and CUPRAC methods) in order to venerate the many authors' recommendation for using several methods for plant antioxidant activity assessment (Schlesier $\boldsymbol{e t}$ al., 2002). The results are presented in Table 2 . The values ranged from $50.94 \pm 0.28$ to $282.81 \pm 3.16 \mu \mathrm{M} \mathrm{TE} / \mathrm{g} \mathrm{DW}$. The highest results in respect of the antiradical activity (DPPH and ABTS assays) were established in the decoction - 115.49 \pm 0.37 and $229.73 \pm 7.41 \mu \mathrm{M}$ TE/g DW. These results were in contrary to the highest values for the tincture in respect of FRAP and CUPRAC assays $\left(F e^{3+}\right.$ and $\mathrm{Cu}^{2+}$ reducing activity) revealing the higher ability of the decoction to scavenge 
free radicals. The established antioxidant activity could be attributed to the extracted compounds such as flavonoids, which show strong antioxidant activity according to some research studies (Yagi et al., 1994; Haraguchi et al., 2002) The obtained results confirmed the recommendations for at least three methods for assessing in vitro antioxidant activity.

In most of the available research studies, regarding the antioxidant activity of water pepper results were expressed as $\mathrm{EC}_{50}\left(\mathrm{IC}_{50}\right)$ or \% inhibition. Ayaz et al. (2014) established $\mathrm{EC}_{50}$ in an aqua fraction of the plant to be $90.56 \%$ toward the ABTS assay, which is comparable to a positive control ascorbic acid with $\mathrm{IC}_{50}$ values of $0.01 \mu \mathrm{g} / \mathrm{ml}$. Using the DPPH assay a significant free radical scavenging activity with $\mathrm{IC}_{50}$ value of $12.211 \mu \mathrm{g} / \mathrm{ml}$ of an ethanol extract was reported (Sharif et al., 2013).

Phenolic acids constitute a group of potentially immunostimulating compounds They occur in all medicinal plants and are widely used in phytotherapy and plant origin foods. In recent years, phenolic acids have attracted much interest owing to their biological functions. Phenolic acids are another group of phytochemicals with serious contribution to the benefit activities of medicinal plants (Barbieri $\boldsymbol{e}$ al., 2017).

\begin{tabular}{|c|c|c|c|c|}
\hline Extraction technique & ABTS & DPPH & FRAP & CUPRAC \\
\hline Infusion & $69.69 \pm 1.50$ & $50.94 \pm 0.28$ & $84.32 \pm 0.44$ & $86.16 \pm 0.95$ \\
\hline Decoction & $229.73 \pm 7.41$ & $115.49 \pm 0.37$ & $147.43 \pm 3.12$ & $205.71 \pm 0.01$ \\
\hline Microwave & $118.76 \pm 1.81$ & $91.33 \pm 1.18$ & $118.16 \pm 0.79$ & $135.69 \pm 3.82$ \\
\hline Tincture & $111.67 \pm 0.91$ & $100.19 \pm 1.11$ & $162.73 \pm 1.3$ & $282.81 \pm 3.16$ \\
\hline
\end{tabular}

Table 3 presents the detailed phytochemical profile in respect of phenolic acids. The total amount of the established phenolic acids ranged from 1411.6 to 3243.74 $\mu \mathrm{g} / \mathrm{g}$ DW. The lowest values were detected in the microwave extract. The predominant established compounds were gallic and chlorogenic acids. Rosmarinic, ferulic, sinapic and cichoric acids were absent from the extracts. The highest total phenolic acids value was established in water pepper tincture and decoction - 3243.74 and $2360.11 \mu \mathrm{g} / \mathrm{g}$ DW, resp. Ayaz et al. (2016) identified bioactive compounds such as 4-methyloxazole, succinimide, pyrocatechol, caryophyllene, vanillic acid, farnesol, myristic acid, arachidic acid methyl ester and capsaicin in GC-MS analysis of $P$. hydropiper methanolic extract.

Table 3 Phenolic acids composition of $P$. hydropiper (water pepper) extracts $(\mu \mathrm{g} / \mathrm{g} \mathrm{dw})$

\begin{tabular}{|c|c|c|c|c|c|c|c|c|c|c|c|}
\hline $\begin{array}{l}\text { Extraction } \\
\text { technique }\end{array}$ & gallic acid & $\begin{array}{l}\text { protocate- } \\
\text { chuic acid }\end{array}$ & $\begin{array}{l}\text { chlorogenic } \\
\text { acid }\end{array}$ & $\begin{array}{c}\text { caffeic } \\
\text { acid }\end{array}$ & $\begin{array}{c}\text { ferulic } \\
\text { acid }\end{array}$ & $\begin{array}{c}\text { p-coumaric } \\
\text { acid }\end{array}$ & $\begin{array}{c}\text { sinapic } \\
\text { acid }\end{array}$ & $\begin{array}{l}\text { rosmarinic } \\
\text { acid }\end{array}$ & $\begin{array}{l}\text { cichoric } \\
\text { acid }\end{array}$ & $\begin{array}{l}\text { cinnamic } \\
\text { acid }\end{array}$ & $\begin{array}{c}\text { total } \\
\text { phenolic } \\
\text { acids }\end{array}$ \\
\hline Infusion & 1056.84 & 68.97 & 435.91 & 33.27 & - & 7.78 & - & - & - & 32.44 & 1635.21 \\
\hline Decoction & 1686.89 & 145.52 & 477.91 & 38.12 & - & 11.67 & - & - & - & - & 2360.11 \\
\hline Microwave & 907.13 & 62.94 & 412.68 & - & - & - & - & - & - & 28.85 & 1411.60 \\
\hline Tincture & 148.48 & 1478.26 & 1503.53 & 56.52 & - & - & - & - & - & 56.95 & 3243.74 \\
\hline
\end{tabular}

\section{CONCLUSION}

The present study aimed at evaluating different extraction techniques in order to draw biologically active substances of $P$. hydropiper (water pepper). In this regard, four procedures were conducted and the phytochemical results obtained revealed water pepper as a good source of polyphenolic compounds, especially flavonoids and phenolic acids. The investigated samples consisted of bioactive compounds in moderate amounts, which could be possible due to the influence of the extraction process itself. The reported data provide valuable information about the most suitable extraction approach of $P$. hydropiper as a source of beneficial health effects.

Acknowledgments: The authors gratefully acknowledge the financial support of the Ministry of Education and Science (Bulgaria), grant agreement № DM 07/2.

\section{REFERENCES}

AMAROWICZ, R., PEGG, R.B., RAHIMI-MOGHADDAM, P., BARL, B. WEIL, J.A. 2004. Free-radical scavenging capacity and antioxidant activity of selected plant species from the Canadian prairies. Food Chem. 84, 551-562 https://doi.org/10.1016/S0308-8146(03)00278-4

AOAC Official Method 2005.02. 2005 Total Monomeric Anthocyanin Pigment Content of Fruit Juices, Beverages, Natural Colorants, and Wines. Journal of AOAC International, 88, 1269.

APAK, R., GÜÇLÜ, K., ÖZYÜREK, M., KARADEMIR, S.E., 2004. Novel total antioxidant capacity index for dietary polyphenols and vitamins $\mathrm{C}$ and $\mathrm{E}$, using their cupric ion reducing capability in the presence of neocuproine: CUPRAC method. J. Agric. Food Chem 52, 7970-7981. https://doi.org/10.1021/jf048741x AYAZ M., JUNAID M., AHMED J., ULLAH F., SADIQ A., AHMAD S., IMRAN M. 2014. Phenolic contents, antioxidant and anticholinesterase potentials of crude extract, subsequent fractions and crude saponins from Polygonum hydropiper L.BMC Complement Altern. Med., 14, 145 https://doi.org/10.1186/1472-6882-14-145

AYAZ, M., JUNAID, M., ULLAH, F., SADIQ, A., KHAN, M.A., AHMAD, W., SHAH, M.R., IMRAN, M., AHMAD, S. 2015. Comparative chemical profiling, cholinesterase inhibitions and anti-radicals properties of essential oils from Polygonum hydropiper L.: A Preliminary anti- Alzheimer's study. Lipids Health Dis. https://doi.org/10.1186/s12944-015-0145-8

AYAZ, M., JUNAID, M., ULLAH, F., SADIQ, A., OVAIS, M., AHMAD, W. AHMAD, S., ZEB, A. 2016. Chemical profiling, antimicrobial and insecticidal evaluations of Polygonum hydropiper L. BMC Complement. Altern. Med. 16(1), 502 https://doi.org/10.1186/s12906-016-1491-4

BALASUNDRAM, N., SUNDRAM, K., SAMMAN, S. 2006. Phenolic compounds in plants and agri-industrial by-products: Antioxidant activity, occurrence, and potential uses. Food Chem. 99, 191-203 https://doi.org/10.1016/j.foodchem.2005.07.042

BARBIERI, R., COPPO, E., MARCHESE, A., DAGLIA, M., SOBARZOSÁNCHEZ, E., NABAVI, S.F., NABAVI, S.M. 2017. Phytochemicals for human disease: An update on plant-derived compounds antibacterial activity. Microbiol. Res. 196, 44-68 https://doi.org/10.1016/j.micres.2016.12.003

BENZIE, I.F.F., STRAIN, J.J. 1999. [2] Ferric reducing/antioxidant power assay: Direct measure of total antioxidant activity of biological fluids and modified version for simultaneous measurement of total antioxidant power and ascorbic acid concentration, in: Methods in Enzymology. 299, 15- 27 https://doi.org/10.1016/S0076-6879(99)99005-5

BRAND-WILLIAMS, W., CUVELIER, M.E., BERSET, C. 1995. Use of a free radical method to evaluate antioxidant activity. LWT - Food Sci. Technol 28, 25 30. https://doi.org/10.1016/S0023-6438(95)80008-5

CHAN, Y.-C., WANG, M.-F., CHEN, Y.-C., YANG, D.-Y., LEE, M.-S., CHENG, F.-C. 2003. Long-term administration of Polygonum multiflorum Thunb. reduces cerebral ischemia-induced infarct volume in gerbils. Am. J. Chin. Med. 31, 71-77 https://doi.org/10.1142/S0192415X03000734

CHEN, L.-W., WANG, Y.-Q., WEI, L.-C., SHI, M., CHAN, Y.-S. 2007. Chinese herbs and herbal extracts for neuroprotection of dopaminergic neurons and potential therapeutic treatment of Parkinson's disease. CNS Neurol. Disord. Drug Targets. 6, 273-281 https://doi.org/10.2174/187152707781387288

HARAGUCHI, H., HASHIMOTO K, YAGI, A. 1992. Antioxidative Substances in Leaves of Polygonum Hydropiper. Journal of Agricultural and Food Chemistry. https://doi.org/10.1021/jf00020a011

HARAGUCHI, H., HASHIMOTO, K., YAGI, A., 2002. Antioxidative Substances in Leaves of Polygonum hydropiper. J. Agric. Food Chem. 40(8), 1349-1351 https://doi.org/10.1021/jf00020a011

HARAGUCHI, H., OHMI, I., SAKAI, S., FUKUDA, A., TOIHARA, Y., FUJIMOTO, T., OKAMURA, N., YAGI, A. 1996. Effect of Polygonum hydropiper sulfated flavonoids on lens aldose reductase and related enzymes. $J$. Nat. Prod 59, 443-445. https://doi.org/10.1021/np9601622

IVANCHEVA, S., STANCHEVA, B. 2001 Ethnobotany in Bulgaria. Plants Balk. Penins. Next Millenn 1, 555-568

KIVRAK, I., DURU, M.E., ÖZTÜRK, M., MERCAN, N., HARMANDAR, M., TOPCU, G. 2009. Antioxidant, anticholinesterase and antimicrobial constituents from the essential oil and ethanol extract of Salvia potentillifolia. Food Chem. 116 (2), 470-479 https://doi.org/10.1016/j.foodchem.2009.02.069

KUJALA, T.S., LOPONEN, J.M., KLIKA, K.D., PIHLAJA, K. 2000. Phenolics and betacyanins in red beetroot (Beta vulgaris) root: Distribution and effect of cold storage on the content of total phenolics and three individual compounds. $J$. Agric. Food Chem. 8, 5338-5342 https://doi.org/10.1021/jf000523q

LI, X., MATSUMOTO, K., MURAKAMI, Y., TEZUKA, Y., WU, Y., KADOTA, S. 2005. Neuroprotective effects of Polygonum multiflorum on 
nigrostriatal dopaminergic degeneration induced by paraquat and maneb in mice. $\begin{array}{llll}\text { Pharmacol. Biochem. } & \text { Behav. } & \text { 32, } & \text { 345-352 }\end{array}$ https://doi.org/10.1016/j.pbb.2005.09.004

LOI, T.D. 2000. The glossary of Vietnamese medicinal plants and items. Hanoi Medicine Publishing House, Hanoi, Vietnam, 283-284

MIHAYLOVA, D., LANTE, A., KRASTANOV, A. 2015 Total phenolic content, antioxidant and antimicrobial activity of Haberlea rhodopensis extracts obtained by pressurized liquid extraction. Acta Aliment. 44 (3), $326-332$.

MIYAZAWA, M., TAMURA, N., 2007. Inhibitory compound of tyrosinase activity from the sprout of Polygonum hydropiper L.(Benitade). Biol. Pharm. Bull. 30, 595-597 https://doi.org/10.1248/bpb.30.595

NACZK, M., SHAHIDI, F. 2006. Phenolic in cereals, fruit and vegetables: Occurrence, extraction and analysis J. Pharm. Biomed. Anal., 41(5), 1523-1542. NURAIN, A., NORIHAM, A., ZAINON, M.N., WAN SAIDATUL, W.S.K., KHAIRUSY, S.Z. 2013. Comparative study of aqueous and ethanolic aromatic malaysian herbs extracts using four antioxidant activity assays. Int. J. Agric. Res. 8, 55-66 https://doi.org/10.3923/ijar.2013.55.66

PENG, Z., STRACK D., BAUMERT A., SUBRAMANIAM R., GOH N.K., CHIA T.F., TAN S.N., CHIA L.S. 2003. Antioxidant flavonoids from leaves of Polygonum hydropiper L. Phytochemistry. 62, 219-228 https://doi.org/10.1016/S0031-9422(02)00504-6

RE, R., PELlEGRINI, N., PROTEGGENTE, A., PANNAlA, A., YANG, M., RICE-EVANS, C., 1999. Antioxidant activity applying an improved ABTS radical cation decolorization assay. Free Radic. Biol. Med. 26, 12311237 https://doi.org/10.1016/S0891-5849(98)00315-3

SCHLESIER, K., HARWAT, M., BÖHM, V., BITSCH, R. 2002. Assessment of antioxidant activity by using different in vitro methods. Free Radic. Res. 36(2), 177-187 https://doi.org/10.1080/10715760290006411

SHARIF, S., M. SHAHRIAR, M.A. HAQUE, Z.S. CHOWDHURY, M.R. ISLAM, BHUIYAN M.A. 2013. In-vitro antioxidant activities, anti-nociceptive and neuropharmacological activities of Polygonum hydropiper. Journal of Biology, Agriculture and Healthcare 3(19), 61-71

SHARMA, R. 2003. Medicinal Plants of India-An Encyclopedia; Daya Publishing House:Delhi, India, 46-47.

TERZIEVA, A.V., VRANCHEVA, R.Z., DELCHEV, N.D. 2017. Antioxidant activity of different extracts of dried and frozen fruits of Schisandra chinensis (Turcz.) Baill Bulg. Chem. Commun., 49(G), $78-82$

YAGI, A., UEMURA, T., OKAMURA, N., HARAGUCHI, H., IMOTO, T., HASHIMOTO, K. 1994. Antioxidative sulphated flavonoids in leaves of Polygonum hydropiper. Phytochemistry. 35, 885-887 https://doi.org/10.1016/S0031-9422(00)90632-0

ZULFIKER, A.H.M., AHMED, D., ALAM, M.B., SAHA, M.R., SAHA, S.K., KHALIL, MD.I., MENON, T.M., RANA, MD.S. 2011. Phenolic content and in vitro antioxidant potential of selected medicinal plants of Bangladesh J. Pharm. Res., 4, 1991-1998. 